\title{
Penyuluhan Hukum Upaya Penanggulangan Tindak Pidana Narkotika di Kalangan Remaja
}

\author{
Rahman Amin ${ }^{1,{ }^{*}}$, Iren Manalu ${ }^{1}$, Muh Fikri Al Aziz ${ }^{1}$, Ishanti Nurjanah Rahayu ${ }^{1}$, \\ Winda Apricilya Van Hemert ${ }^{1}$, Alffin Pratama ${ }^{1}$, Indah Tri Lestari ${ }^{1}$ \\ ${ }^{1}$ Fakultas Hukum; Universitas Bhayangkara Jakarta Raya; Jln. Raya Perjuangan, \\ Marga Mulya, Bekasi Utara, Jawa Barat 17121, 02188955882/ +622188955871; e-mail: \\ rahman.amin2013@gmail.com, irenmanalu20@gmail.com, fikrialaziz86@gmail.com, \\ santiihsanti@gmail.com, windaavh@gmail.com, alfincoutinho@gmail.com, \\ sugandaindah@gmail.com \\ *Korespondensi: e-mail: rahman.amin2013@gmail.com
}

Submitted: 15/06/2021; Revised: 23/06/2021; Accepted: 26/06/2021; Published: 28/06/2021

\begin{abstract}
Teenagers are the next generation of the ideals of the struggle of the Indonesian nation and state who have a very significant role and position in determining the future of the nation and state in the future. But in reality, today many young people in this case are teenagers who are involved in various cases of law violations, especially narcotics abuse which can have a negative impact on their development. For this matter, the Lecturer of the Faculty of Law, Bhayangkara University, Greater Jakarta, carried out community service activities in the form of legal counseling regarding efforts to overcome narcotics crime among youth at Karang Taruna RW 6 Sekeloa Village, Coblong District, Bandung City. The results of the activity showed that before attending legal counseling, adolescents' knowledge and understanding of narcotics crimes was still minimal, and after the implementation of legal counseling, adolescents' knowledge and understanding of narcotics crimes increased. The output of this activity is stated in a report on the implementation of activities and published in scientific journals so that it can provide benefits for academics and the wider community.
\end{abstract}

Keywords: Countermeasures, Narcotics Crime, Teenagers

\begin{abstract}
Abstrak
Remaja merupakan generasi penerus cita-cita perjuangan bangsa dan negara Indonesia yang mempunyai peran dan kedudukan yang sangat signifikan dalam menentukan masa depan bangsa dan negara di masa yang akan datang. Namun dalam kenyataannya, dewasa ini banyak generasi muda dalam hal ini remaja yang terlibat dalam berbagai kasus pelanggaran hukum khususnya penyalahgunaan narkotika yang dapat berdampak negatif bagi perkembangannya. Atas hal tersebut, Dosen Fakultas Hukum Universitas Bhayangkara Jakarta Raya melaksanakan kegiatan pengabdian masyarakat dalam bentuk penyuluhan hukum tentang upaya penanggulangan tindak pidana narkotika di kalangan remaja Karang Taruna RW 6 Kelurahan Sekeloa, Kecamatan Coblong, Kota Bandung. Hasil kegiatan menunjukkan bahwa sebelum mengikuti penyuluhan hukum, pengetahuan dan pemahaman remaja tentang tindak pidana Narkotika masih minim, dan setelah pelaksanaan penyuluhan hukum, pengetahuan dan pemahaman remaja tentang tindak pidana Narkotika semakin meningkat. Luaran kegiatan ini dituangkan dalalm laporan pelaksanaan kegiatan dan dimuat dalam jurnal ilmiah sehingga dapat memberikan manfaat bagi kalangan akademisi dan masyarakat luas.
\end{abstract}

Kata kunci: Penanggulangan, Tindak Pidana Narkotika, Remaja 
Rahman Amin, Iren Manalu, Muh Fikri Al Aziz, Ishanti Nurjanah Rahayu, Winda Apricilya Van Hemert, Alffin Pratama, Indah Tri Lestari

\section{Pendahuluan}

Remaja merupakan bagian dari generasi muda yang mempunyai peran yang sangat signifikan dalam mengisi dan melanjutkan cita-cita perjuangan bangsa. Remaja sebagai generasi penerus yang akan mengisi dan menyelenggarakan pembangunan bangsa dan negara di masa yang akan datang. Di tangan dan pundak generasi muda, masa depan dan cita-cita bangsa dan negara diletakkan karena generasi muda kelak akan menjadi pemimpin pada masa depan yang akan melanjutkan tongkat estafet pembangunan dari generasi terdahulu menuju ke arah yang lebih baik. Generasi muda dalam hal ini remaja merupakan subyek dan obyek pembangunan nasional dalam rangka mencapai tujuan dan cita-cita bangsa Indonesia yakni mewujudkan masyarakat yang adil, makmur dan sejahtera berdasarkan Pancasila dan UUD 1945.

Generasi muda mempunyai peranan yang sangat penting, dimulai dari peristiwa Sumpah Pemuda pada tanggal 28 Oktober 1928 yang merupakan peristiwa sejarah perjuangan bangsa Indonesia hingga proklamasi kemerdekaan bangsa Indonesia pada tanggal 17 Agustus 1945 yang merupakan tonggak sejarah berdirinya negara Indonesia sebagai bangsa yang merdeka. Begitu besar peranan pemuda sebagaimana dikemukakan oleh Soekarno yang menyatakan kalimat "beri aku 10 pemuda, niscaya akan ku guncangkan dunia", hal tersebut mempunyai makna filosofis yang mendalam adanya suatu keyakinan pendiri bangsa Indonesia terhadap pemuda bangsa yang merupakan aset yang sangat berharga dan memiliki peranan yang sangat penting dalam menentukan arah dan nasib bangsa Indonesia dalam mencapai tujuan dan cita-citanya.

Selanjutnya, pada masa setelah Indonesia merdeka, pemuda yang merupakan generasi penerus cita-cita perjuangan bangsa Indonesia mempunyai peran yang sangat strategis untuk mengisi dan menyelenggarakan pembangunan di segala bidang kehidupan. Pemuda diharapkan menjadi pelopor yang tidak hanya sebagai obyek pembangunan namun juga dapat menjadi subyek dalam pembangunan bangsa dan negara Indonesia. Sebagai generasi penerus perjuangan bangsa, pemuda mempunyai hak dan kewajiban dalam penyelenggaraan pembangunan, oleh karena itu pemuda harus mempunyai bekal kemampuan dan kompetensi yang memadai dalam menghadapi dinamika perkembangan zaman yang terjadi dewasa ini agar bangsa dan negara Indonesia tidak tertinggal dengan kemajuan bangsa dan negara lain di dunia Internasional.

Namun menjadi suatu permasalahan serius yang sedang dihadapi saat ini adalah maraknya peristiwa pelanggaran hukum yang melibatkan generasi muda dalam hal ini remaja yang merupakan suatu permasalahan yang dihadapi oleh setiap negara tidak terkecuali Indonesia sehingga menimbulkan kekhawatiran terhadap masa depan generasi muda Indonesia. Sebagai gambaran semakin maraknya kasus-kasus pelanggaran hukum yang dilakukan oleh remaja yang dapat dilihat dari media cetak atau elektronik antara lain peristiwa perkelahian atau tawuran antara remaja sekolah, konsumsi miras, pencurian, perampokan, penyalahgunaan narkotika dan pelanggaran hukum lainnya. Hal tersebut dapat memberikan 
gambaran bahwa generasi muda yang merupakan penerus masa depan bangsa, justru melakukan perbuatan yang melanggar hukum.

Terkait dengan penyalahgunaan Narkotika, secara umum pengertian Narkotika tercantum dalam Pasal 1 Angka 1 Undang-Undang Nomor 35 Tahun 2009 tentang Narkotika, yaitu Narkotika adalah zat atau obat yang berasal dari tanaman atau bukan tanaman baik sintetis maupun semi sintetis yang dapat menyebabka menurunnya atau perubahan kesadaran, hilangnya rasa, mengurangi sampai menghilangkan rasa nyeri, dan dapat menimbulkan ketergantungan, yang dibedakan dalam golongan sebagaimana terlampir dalam undangundang ini.

Menurut Ensiklopedia Indonesia, narkotika secara farmakologis medis adalah obat yang dapat menghilangkan (terutama) rasa nyeri yang berasal dari daerah Viseral dan yang dapat menimbulkan efak stupor (bengong, masih sadar tetapi harus digertak) serta adiksi (Sasangka, 2003). Narkotika merupakan zat yang dapat memberikan berpengaruh pada otak sehingga menimbulkan perubahan pada perilaku, perasaan, pikiran, persepsi, kesadaran, halusinasi, di samping dapat digunakan untuk pembiusan. Dulu narkotika di Indonesia dikenal dengan sebutan madat, sedangkan di Malaysia, narkotika disebut dengan dadah (Makaro \& Taufik, 2005)

Merriam-Webster memberikan penjelasan mengenai narkotika yaitu pertama obat (seperti opium atau morfin) yang dalam dosis tertentu dapat menumpulkan indera, mengurangi rasa sakit, dan mendorong tidur, tetapi dalam dosis berlebihan menyebabkan pingsan, koma, atau kejang. Kedua obat (seperti ganja atau $L S D$ ) dalam batasan tertentu yang serupa dengan bahan adiktif, apakah fisiologis adiktif dan narkotika, dan ketiga dapat menenangkan, mengurangi, atau menidurkan (Sujono \& Daniel, 2013).

Selanjutnya, ditinjau dari asalnya, pada dasarnya narkotika berasal dari alam dan hasil proses kimia (sintetis), Wresniworo (1999) menyatakan bahwa menurut cara atau proses pengolahannya, narkotika dapat dibagi menjadi tiga golongan, yaitu narkotika alam, narkotika semi sintetis dan narkotika sintetis.

Narkotika alam adalah narkotika yang berasal dari hasil olahan tanaman yang dapat dikelompokkan dari tiga jenis tanaman, pertama opium atau candu, yaitu hasil olahan getah dari buah tanaman papaver somniferum. Yang termasuk dalam kelompok ini adalah opium mentah, opium masak dan morfin. Jenis opium ini berasal dari luar negeri yang diselundupkan ke Indonesia, karena jenis tanaman ini tidak terdapat di Indonesia, kedua Kokain, yang berasal dari olahan daun tanaman koka yang banyak terdapat dan diolah secara gelap di Amerika bagian selatan seperti Peru, Bolivia, Kolombia, dan ketiga Canabis Sativa atau marihuana atau yang disebut ganja termasuk hashish oil (minyak ganja). Tanaman ganja ini banyak ditanam secara ilegal didaerah khatulistiwa khususnya di Indonesia terdapat di Aceh. Narkotika semi sintetis, yang dimaksud dengan Narkotika golongan ini adalah narkotika yang dibuat dari alkaloida opium dengan inti penathren dan diproses secara kimiawi untuk menjadi bahan obat yang berkhasiat sebagai narkotika. Contoh yang terkenal dan sering disalahgunakan adalah 
Rahman Amin, Iren Manalu, Muh Fikri Al Aziz, Ishanti Nurjanah Rahayu, Winda Apricilya Van Hemert, Alffin Pratama, Indah Tri Lestari

heroin dan codein. Narkotika sintetis, narkotika golongan ini diperoleh melalui proses kimia dengan menggunakan bahan baku kimia, sehingga diperoleh suatu hasil baru yang mempunyai efek narkotika seperti Pethidine, Metadon dan Megadon.

Selain penggolongan Narkotika menurut asal perolehannya tersebut, juga dikenal penggolongan Narkotika dari segi penggunaannya sebagaimana diatur dalam Pasal 6 Ayat 1 Undang-Undang Nomor 35 Tahun 2009 tentang Narkotika, yaitu Narkotika Golongan I, Narkotika Golongan II dan Narkotika Golongan III.

Narkotika Golongan I adalah narkotika yang hanya digunakan untuk tujuan ilmu pengetahuan dan tidak digunakan dalam terapi serta mempunyai potensi yang sangat tinggi mengakibatkan ketergantungan. Narkotika Golongan II adalah narkotika berkhasiat pengobatan digunakan sebagai pilihan terakhir dan dapat digunakan dalam terapi dan/atau untuk tujuan pengembangan ilmu pengetahuan serta mempunyai potensi yang tinggi mengakibatkan ketergantugan. Narkotika Golongan III adalah narkotika berkhasiat pengobatan dan banyak digunakan dalam terapi dan/atau untuk tujuan ilmu pengembangan pengetahuan serta mempunyai potensi ringan mengakibatkan ketergantungan.

Dari penggolongan tersebut, dapat dikatakan bahwa Narkotika hanya dapat digunakan untuk kepentingan pelayanan kesehatan dan pengembangan ilmu pengetahuan dan tekonologi sebagaimana diatur dalam Pasal 7 Undang-Undang Nomor 35 Tahun 2009 tentang Narkotika, sehingga dapat disimpulkan bahwa penggunaan narkotika yang sesuai dengan peruntukannya yakni untuk pelayanan kesehatan, untuk kepentingan penelitian dan pengembangan ilmu pengetahuan serta dilengkapi dengan izin resmi dari instansi yang berwenang, maka tidak dapat dikualifikasikan sebagai tindak pidana Narkotika, namun jika Narkotika digunakan selain untuk tujuan yang telah ditentukan serta tanpa izin yang sah maka perbuatan tersebut merupakan sebagai tindak pidana Narkotika.

Adapun penggunaan Narkotika hanya untuk kepentingan pelayanan kesehatan dan pengembangan ilmu pengetahuan dan teknologi yang dilakukan melalui kegiatan pengendalian, pengawasan secara ketat dan seksama dan harus mempunyai izin yang secara resmi dikeluarkan oleh pejabat yang berwenang menurut ketentuan yang berlaku. Izin penggunaan Narkotika tersebut sebagaimana tercantum dalam Undang-Undang Nomor 35 Tahun 2009 tentang Narkotika yaitu izin khusus dan surat persetujuan impor Narkotika, izin khusus dan surat persetujuan ekspor Narkotika, izin produksi Narkotika, izin untuk kepentingan ilmu pengetahuan dan teknologi, izin edar Narkotika, dan izin khusus penyaluran Narkotika (Siswanto, 2012).

Selanjutnya, kualifikasi tindak pidana Narkotika diatur Undang-Undang Nomor 35 Tahun 2009 tentang Narkotika sebagaimana teracantum dalam Pasal 111 sampai dengan Pasal 148 Bab. XV tentang ketentuan pidana Undang-Undang Nomor 35 Tahun 2009 tentang narkotika, memberikan pengaturan tentang bentuk-bentuk/kualifikasi tindak pidana narkotika yang dapat dikelompokan sebagai berikut: 1) Tindak pidana berkaitan dengan produksi Narkotika; 2) Tindak pidana berkaitan dengan jual beli Narkotika; 3) Tindak pidana berkaitan 
dengan pengangkutan dan transito Narkotika; 4) Tindak pidana berkaitan dengan penguasaan Narkotika; 5) Tindak pidana berkaitan dengan penyalahgunaan Narkotika; 6) Tindak pidana berkaitan dengan tidak melaporkan pecandu Narkotika; 7) Tindak pidana berkaitan dengan jalannya peradilan Narkotika; 8) Tindak pidana berkaitan dengan penyitaan dan pemusnahan Narkotika; 9) Tindak pidana berkaitan dengan keterangan palsu; 10) Tindak pidana berkaitan dengan penyimpangan kewenangan lembaga.

Dewasa ini, tindak pidana Narkotika menunjukkan trend perkembangan yang signifikan baik secara kualitas maupun kuantitas yang semakin meningkat dari waktu-kewaktu sehingga mempunyai dampak sangat merugikan bagi individu maupun masyarakat luas termasuk bagi generasi muda itu sendiri sehingga dapat mengancam masa depan bangsa Indonesia. Oleh karena itu, untuk menanggulangi tindak pidana narkotika khususnya yang melibatkan remaja sebagai generasi muda merupakan suatu permasalahan yang sangat kompleks memerlukan upaya penanggulangan yang komprehensif dengan melibatkan kerjasama antara multidispliner, multi sektor dan peran serta dari seluruh lapisan masyarakat secara aktif yang dilaksanakan secara berkesinambungan, konsekuen dan konsisten sehingga dapat melindungi bangsa Indonesia dari bahaya penyalahgunaan Narkotika.

Sehubungan dengan itu, upaya menanggulangi kejahatan atau tindak pidana termasuk ke dalam kerangka politik kriminal (criminal politic). Di sinilah peranan yang sangat penting dari politik kriminal, yaitu dengan mengerahkan semua usaha yang rasional untuk mengendalikan atau menanggulangi kejahatan. Sebagaimana dikemukakan oleh G. Peter Hoefnagels bahwa kebijakan penanggulangan pidana (criminal policy) dapat ditempuh melalui 3 cara, yaitu pertama criminal law application (penerapan hukum pidana) yaitu melalui upaya penegakan hukum pidana, kedua prevention without punisment (pencegahan tanpa pidana) melalui upaya pembinaan kepada masyarakat, dan ketiga influencing views of society on crime and punisment (mempengaruhi pandangan masyarakat mengenai kejahatan dan pemidanaan lewat mass media (Arief, 2010).

Dari uraian tersebut di atas, maka untuk memberikan pengetahuan dan pemahaman kepada remaja yang merupakan generasi muda penerus cita-cita perjuangan bangsa dan Negara Indonesia, maka perlu dilaksanakan kegiatan pengabdian masyarakat dalam bentuk penyuluhan hukum tentang ketentuan tindak pidana Narkotika dan upaya penanggulangannya sehingga melalui penyuluhan hukum tersebut diharapkan dapat memberikan bekal pengetahuan dan pemahaman kepada remaja sehingga dapat menumbuhkan kesadaran dan kepatuhan hukum agar tidak terjerumus dalam penyalahgunaan dan peredaran gelap Narkotika yang dapat mengancam masa depan generasi muda bangsa dan negara Indonesia.

Berdasarkan latar belakang tersebut di atas, dapat diindentifikasi masalah sebagai berikut; Pertama kurangnya pengetahuan dan pemahaman remaja tentang tindak pidana Narkotika dan upaya penanggulangannya, Kedua kurangnya sosialisasi dan penyuluhan kepada remaja tentang tindak pidana Narkotika dan upaya penanggulangannya. 
Rahman Amin, Iren Manalu, Muh Fikri Al Aziz, Ishanti Nurjanah Rahayu, Winda Apricilya Van Hemert, Alffin Pratama, Indah Tri Lestari

\section{Metode Pelaksanaan}

Kegiatan pengabdian kepada masyarakat dalam bentuk penyuluhan hukum ini dilaksanakan pada hari Sabtu tanggal 10 April 2021, dimulai pukul 09.00 s.d 13.00 WIB bertempat di meeting room Hotel Neo yang terletak di Jln. Sekeloa, Kel. Sekeloa, Kec. Coblong, Kota Bandung Jawa Barat. Adapun sasaran kegiatan pengabdian kepada masyarakat ini ditujukan kepada Anggota Karang Taruna RW 6 Kelurahan Sekeloa, Kec. Coblong, Kota Bandung yang merupakan generasi muda penerus cita-cita perjuangan bangsa dan negara Indonesia.

Adapun metode pelaksanaan kegiatan pengabdian kepada masyarakat dalam bentuk penyuluhan hukum ini dilaksanakan dengan tahapan yaitu pertama tahap persiapan meliputi survei ke lokasi Karang Taruna RW 06 Kelurahan Sekoloa Kecamatan Coblong Kota Bandung, membuat proposal penyuluhan berdasarkan hasil survei, melaksanakan koordinasi dengan pengurus Karang Taruna RW 06, Lurah Kelurahan Sekeloa serta mempersiapkan tempat kegiatan penyuluhan, pengadaan alat dan bahan yang akan digunakan, penyusunan bahan dan materi presentasi yang akan disampaikan kepada peserta penyuluhan, dan rapat konsolidasi sebelum berangkat ke lokasi kegiatan. Kedua, kegiatan penyuluhan terdiri dari pembukaan dilanjutkan sambutan dan perkenalan panitia pelaksana kepada peserta penyuluhan, pelaksanaan pre-test kepada peserta penyuluhan, penyampaian materi penyuluhan tentang upaya penanggulangan tindak pidana Narkotika di kalangan remaja, sesi diskusi berkaitan dengan materi penyuluhan, dan kesimpulan pelaksanaan penyuluhan. Ketiga, Penutupan kegiatan meliputi pelaksanaan post-test, penyerahan cindera mata kepada Lurah Kelurahan Sekola, kata penutup permohonan maaf apabila ada kekurangan dan ucapan terima kasih dari panitia kepada peserta penyuluhan.

Kegiatan pengabdian kepada masyarakat dalam bentuk penyuluhan hukum upaya penanggulangan tindak pidana Narkotika di kalangan remaja secara umum ditujukan kepada pemuda yang merupakan generasi muda penerus cita-cita perjuangan bangsa dan negara Indonesia, khususnya kepada remaja yang rentan terjerumus ke dalam tindak pidana Narkotika dalam kehidupannya, dimana kegiatan penyuluhan hukum tersebut dihadiri oleh 20 (dua puluh) orang peserta dengan usia antara 16 s.d 20 tahun yang merupakan anggota Karang Taruna RW 06 Kelurahan Sekeloa Kecamatan Coblong Kota Bandung.

\section{Hasil dan Pembahasan}

Tindak pidana Narkotika merupakan salah satu kejahatan luar biasa yang dapat memberikan dampak yang membahaykan kelangsungan dan masa depan bangsa dan negara, sehingga membutuhkan upaya penanggulangan dengan melibatkan seluruh komponen bangsa dan Negara Indonesia salah satunya melalui upaya pembinaan dan penyuluhan hukum kepada masyarakat tentang ketentuan hukum tentang tindak pidana Narkotika dan bagaimana upaya dalam penanggulangannya sehingga diharapkan dapat memberikan pengetahuan dan pemahaman hukum yang nantinya akan menumbuhkan kesadaran dan kepatuhan hukum. 
Terkait hal tersebut, secara umum kesadaran artinya keadaan ikhlas yang muncul dari hati nurani dalam mengakui dan mengamalkan sesuatu dengan tuntutan yang terdapat di dalamnya. Kesadaran hukum berarti perasaan dan tindakan yang tumbuh dari hati nurani dan jiwa yang terdalam dari manusia sebagai individu atau warga masyarakat untuk melaksanakan pesan-pesan yang terdapat dalam hukum. Kesadaran hukum dapat diartikan sebagai proses emanasi normatif yaitu kesatuan transendental antara kehidupan manusia yang isoterik dengan aturan hukum yang membawa kehidupan pribadi dan kehidupan sosialnya dalam masyarakat (Saebani, 2006).

Kesadaran hukum (legal consciousnees) dapat diartikan sebagai kesadaran yang ada pada setiap manusia tentang apa hukum itu, suatu kategori tertentu dari hidup kejiwaan yang membedakan antara hukum dan tidak hukum (on recht) antara yang seyogyanya dilakukan dan tidak dilakukan. Kesadaran hukum merupakan konsepsi abstrak di dalam diri manusia tentang keserasian antara ketertiban dan ketentraman yang dikehendaki atau sepantasnya. Kesadaran hukum merupakan merupakan kesadaran nilai-nilai yang terdapat dalam diri manusia tentang hukum yang ada atau tentang hukum yang diharapkan ada (Suadi, 2019).

Selain itu, masalah pengetahuan masyarakat mengenai adanya peraturan merupakan faktor yang perlu diperhatikan pada waktu membicarakan kepatuhan masyarakat terhadap hukum. Hubungan antara pengetahuan tentang hukum dan kepatuhan hukum atau perilaku tidak dapat dipastikan bahwa hubungan itu bersifat kausal, dimana pada umumnya masyarakat memiliki pengetahuan yang rendah mengenai isi peraturan, sehingga kepatuhan terhadap hukum berjalan berdampingan dengan pengetahuan yang rendah mengenai hukum. Dengan demikian, bahwa hukum dan pengetahuan mengenai hukum tidak dapat dikatakan sebagai faktor absolut dalam wacana mengenai kepatuhan hukum (Rahardjo, 2010).

Oleh karena itu, untuk meningkatkan kesadaran hukum dan kepatuhan hukum masyarakat, maka dilakukan melalui penyuluhan dan penerangan hukum yang teratur atas dasar perencanaan yang mantap, dimana penyuluhan hukum bertujuan agar warga masyarakat mengetahui dan memahami hukum-hukum tertentu, misalnya peraturan perundang-undangan tertentu. Melalui penyuluhan hukum substansi peraturan peraturan perundang-undangan tersebut dijelaskan agar masyarakat dapat merasakan manfaatnya yang dalam pelaksanaannya penerangan dan penyuluhan hukum harus disesuaikan dengan masalahmasalah hukum yang ada dalam masyarakat pada suatu waktu yang menjadi sasaran penyuluhan hukum (Ali, 2008).

Berdasarkan hal tersebut, secara umum kegiatan pengabdian kepada masyarakat dalam bentuk penyuluhan hukum tentang upaya penanggulangan tindak pidana Narkotika di kalangan remaja berjalan dengan baik dan lancar sesuai dengan rencana tahapan kegiatan penyuluhan hukum yang telah dibuat oleh panitia tanpa ada kendala yang berarti meskipun waktu pelaksanaan kegiatan masih dalam situasi pandemi, namun panitia telah mengambil langkah-langkah antara lain menerapkan protokol kesehatan dengan ketat, yakni membatasi jumlah peserta 1/3 dari kapasitas ruangan yang ada, menyiapkan hand sanitizer, membagikan 
Rahman Amin, Iren Manalu, Muh Fikri Al Aziz, Ishanti Nurjanah Rahayu, Winda Apricilya Van Hemert, Alffin Pratama, Indah Tri Lestari

masker kepada peserta, melakukan pengecekan suhu tubuh sebelum masuk keruangan penyuluhan dengan menggunakan thermogun, serta menyampaikan himbauan kepada peserta penyuluhan agar tetap menerapkan protokol kesehatan selama kegiatan penyuluhan berlangung yakni tetap menjaga jarak dan menggunakan masker.

Kegiatan pengabdian kepada masyarakat dalam bentuk penyuluhan hukum tentang upaya penanggulangan tindak pidana Narkotika di kalarangan remaja yang ditujukan kepada pemuda yang merupakan generasi penerus cita-cita perjuangan bangsa, khususnya remaja yang menjadi anggota Karang Taruna RW 06 Kelurahan Sekeloa Kecamatan Coblong Kota Bandung, dalam pelaksanaannya dari awal hingga akhir mendapat tanggapan dan respon antusias yang sangat tinggi baik oleh Lurah Kelurahan Sekeloa mewakili pihak kelurahan, dan khususnya dari peserta penyuluhan hukum yang telah hadir mengikuti kegiatan penyuluhan tepat waktu yakni pukul $08.30 \mathrm{WIB}$, mengisi absensi, menerapkan protokol kesehatan selama kegiatan, mendengarkan/menyimak penyampaian materi yang disampaikan oleh pemateri, serta sangat aktif dalam memberikan pertanyaan kepada pemateri pada sesi diskusi/tanya jawab, hingga akhir pelaksanaan kegiatan penyuluhan peserta tetab menjaga ketertiban di tempat kegiatan.

Deskripsi umum pelaksanaan kegiatan pengabdian kepada masyarakat dalam bentuk penyuluhan hukum tentang upaya penanggulangan tindak pidana Narkotika di kalangan remaja diawali dengan kegiatan pembukaan kegiatan penyuluhan hukum yang dibawakan oleh master ceremony a.n. WINDA APRICILYA VAN HEMERT yang membuka kegiatan penyuluhan dan memimpin pembacaan doa kepada panitia dan seluruh peserta, penyampaian tata tertib selama kegiatan penyuluhan khususnya penerapan protokol kesehatan, serta penyampaian rundown kegiatan penyuluhan hukum. Acara selanjutnya sambutan dari Ketua Panitia Pelaksana oleh Dr. RAHMAN AMIN, S.H., M.H, dengan mengucapkan maksud dan tujuan kegiatan penyuluhan yang merupakan salah satu bentuk Tridharma Perguruan Tinggi dalam hal ini Universitas Bhayangkara kepada masyarakat khususnya dalam bidang ilmu hukum, serta penyampaian ucapan terima kasih kepada pihak Kelurahan Sekeloa yang telah mendukung pelaksanaan kegiatan penyuluhan dan kepada peserta yang telah bersedia hadir dalam kegiatan penyuluhan.

Kegiatan kemudian dilanjutkan dengan perkenalan panitia pelaksana kepada peserta penyuluhan hukum agar mengenal Panitia kegiatan sehingga dapat terjalin hubungan emosional yang baik selama kegiatan penyuluhan hukum berlangsung. Kemudian sambutan dari Lurah Kelurahan Sekeloa a.n. TIRTA GUMELAR, S.STP. M.TR.IP, yang menyampaikan ucapan terima kasih atas kepercayaan dari Universitas Bhayangkara yang telah memilih Kelurahan Sekeloa sebagai tempat pelaksanaan kegiatan penyuluhan hukum tentang upaya penanggulangan tindak pidana Narkotika di kalangan remaja, dimana kasus penyalahgunaan Narkotika merupakan masalah yang sedang dihadapi oleh bangsa dan Negara Indonesia sehingga membutuhkan upaya penanggulangan dengan melibatkan seluruh komponen bangsa 
untuk melindungi bangsa Indonesia dari bahaya tindak piana Narkotika yang sedang marak terjadi.

Sebelum sesi penyampaian materi dimulai, panitia memberikan pre-test kepada peserta penyuluhan hukum dengan maksud untuk mengetahui dan sebagai gambaran awal bagaimana tingkat pengetahuan dan pemahaman peserta tentang materi penyuluhan yang akan disampaikan kepada peserta penyuluhan. Setelah pelaksanaan pre-test selama 10 menit, kegiatan penyuluhan dilanjutkan dengan sesi penyampaian materi yang dibagi dalam tiga sesi, yaitu sesi pertama disampaikan oleh Sdri. IREN MANALU Mahasiswa Fakultas Hukum Universitas Bhayangkara Jaya Semester IV dengan materi faktor-faktor penyebab penyalahgunaan Narkotika oleh remaja dan dampak negatif penyalahgunaannya, dengan waktu selama 15 menit. Sesi kedua disampaikan oleh Sdri. ZAHRATUNISA mahasiswa Fakultas Psikologi Universitas Bhayangkara Jaya Semester VI dengan materi tinjauan psikologis remaja penyalahguna Narkotika, dengan waktu 15 menit dan sesi ketiga atau sesi utama disampaikan oleh Dr. RAHMAN AMIN, S.H, M.H, Dosen Fakultas Hukum Universitas Bhayangkara Jaya sekaligus sebagai Ketua Kegiatan Pengabdian Masyarakat, dengan materi upaya penanggulangan tindak pidana Narkotika di kalangan remaja, dengan waktu 90 menit.

Setelah sesi penyampaian materi selesai dilaksanakan, kegiatan penyuluhan hukum dilanjutkan dengan sesi diskusi/tanya jawab dari peserta penyuluhan hukum kepada pemateri berkaitan dengan materi penyuluhan hukum yang telah disampaikan yakni tentang upaya penanggulangan tindak pidana Narkotika di kalangan remaja, yang berlangsung selama 30 menit, dimana peserta penyuluhan sangat antusias dan aktif untuk memberikan pertanyaanpertanyaan berkaitan dengan materi yang telah disampaikan, dan kemudian pertanyaanpertanyaan tersebut dijawab langsung oleh pemateri secara detail dan jelas sehingga dapat memberikan jawaban yang tepat sesuai dengan pertanyaan yang diajukan sehingga peserta penyuluhan yang bertanya dapat menjadi paham dan mengerti atas pertanyaan yang diajukan tersebut.

Setelah sesi diskusi/tanya jawab selesai, kemudian panitia memberikan post-test kepada peserta penyuluhan dengan maksud untuk mengetahui sejauhmana tingkat pengetahuan dan pemahaman peserta penyuluhan setelah mengikuti dan menerima materi yang telah disampaikan oleh pemateri selama kegiatan penyuluhan berlangsung. Dari hasil pengerjaan soal post-test pada lembar jawaban yang telah disiapkan oleh panitia, diperoleh hasil adanya peningkatan pengetahuan dan pemahaman yang cukup signifikan oleh peserta berkaitan dengan materi penyuluhan yang telah disampaikan, yang dapat dilihat dari tabel sebagai berikut: 
Rahman Amin, Iren Manalu, Muh Fikri Al Aziz, Ishanti Nurjanah Rahayu, Winda Apricilya Van Hemert, Alffin Pratama, Indah Tri Lestari

Tabel 1. Hasil Pre-test dan Post-test

\begin{tabular}{|c|c|c|c|c|c|}
\hline \multirow{3}{*}{ No. } & \multirow{3}{*}{ Pertanyaan } & \multicolumn{4}{|c|}{ Hasil Test } \\
\hline & & \multicolumn{2}{|c|}{ Pre-Test } & \multicolumn{2}{|c|}{ Post-Test } \\
\hline & & Jumlah & $\%$ & Jumlah & $\%$ \\
\hline 1. & Pengetahuan tentang Narkotika dan jenis-jenisnya & 12 & 60 & 20 & 100 \\
\hline 2. & Pengetahuan tentang dasar hukum Narkotika di Indonesia & 11 & 55 & 19 & 95 \\
\hline 3. & $\begin{array}{l}\text { Pengetahuan tentang penggunaan Narkotika menurut } \\
\text { ketentuan yang berlaku }\end{array}$ & 10 & 50 & 20 & 100 \\
\hline 4. & Pengetahuan tentang kualifikasi tindak pidana Narkotika & 8 & 40 & 18 & 90 \\
\hline 5. & $\begin{array}{l}\text { Pemahaman tentang upaya penanggulangan penyalahgunaan } \\
\text { Narkotika }\end{array}$ & 9 & 45 & 20 & 100 \\
\hline
\end{tabular}

Sumber: Hasil Pelaksanaan (2021)

Dari tabel tersebut di atas dapat dikatakan bahwa adanya peningkatan pengetahuan dan pemahaman peserta penyuluhan hukum yang cukup signifikan setelah mengikuti kegiatan penyuluhan hukum tentang upaya penanggulangan tindak pidana Narkotika di kalangan remaja, dimana sebelum mengikuti kegiatan penyuluhan hukum, peserta masih belum mengetahui dan memahami secara mendalam tentang ketentuan hukum tindak pidana Narkotika menurut peraturan perundang-undangan yang berlaku dan upaya penanggulangannya di kalangan remaja, dan setelah mengikuti kegiatan penyuluhan hukum, sebagian besar peserta penyuluhan telah mengetahui dan memahami ketentuan hukum tentang tindak pidana Narkotika dan upaya penanggulangannya.

Sebagai akhir kegiatan penyuluhan, pantia memberikan cinderamata/kenang-kenangan berupa plakat kepada Lurah Kelurahan Sekeloa sebagai ucapan terima kasih atas dukungan yang telah diberikan, kemudian dilanjutkan dengan sesi foto bersama dan diakhiri dengan ucapan penutup, dan terima kasih kepada peserta penyuluhan atas pelaksanaan kegiatan penyuluhan hukum. Sebelum kembali ke kediaman masing-masing, panitia penyuluhan memberikan konsumsi dalam bentuk nasi kotak dan air mineral kepada peserta untuk dapat dibawa pulang dan dinikmati oleh masing-masing peserta.

\section{Kesimpulan}

Berdasarkan uraian kegiatan pengabdian kepada masyarakat dalam bentuk penyuluhan hukum tentang upaya penanggulangan tindak pidana Narkotika di kalangan remaja yang telah dilaksanakan, dapat disimpulkan sebagai berikut: Pertama, kegiatan pengabdian kepada masyarakat dalam bentuk penyuluhan hukum tentang upaya penanggulangan tindak pidana Narkotika di kalangan remaja yang ditujukan kepada Anggota Karang Taruna RW 06 Kelurahan Sekeloa Kecamatan Coblong Kota Bandung telah terlaksana dengan baik dan lancar sesuai dengan rencana yang telah dibuat oleh panitia tanpa adanya kendala yang berarti dari awal hingga kegiatan berakhir, Kedua, kegiatan pengabdian kepada masyarakat dalam bentuk penyuluhan hukum tentang upaya penanggulangan tindak pidana Narkotika di kalangan remaja mendapat sambutan dan respon yang positif dari peserta penyuluhan yakni Anggota Karang Taruna RW 06 Kelurahan Sekeloa Kecamatan Coblong Kota Bandung yang dapat dilihat dari 
pertanyaan-pertanyaan dan sikap yang antusias dari peserta selama kegiatan penyuluhan hukum berlangsung, Ketiga, kegiatan pengabdian masyarakat dalam bentuk penyuluhan hukum tentang upaya penanggulangan tindak pidana Narkotika di kalangan remaja telah meningkatkan pengetahuan dan pemahaman Anggota Karang Taruna RW 06 Kelurahan Sekeloa Kecamatan Coblong Kota Bandung yang mengikuti kegiatan tentang penyuluhan hukum yang dilaksanakan oleh pantia pelaksana.

Dari kesimpulan pelaksanaan kegiatan pengabdian kepada masyarakat dalam bentuk penyuluhan hukum sebagaimana tersebut di atas, maka disarankan pertama, kiranya kegiatan pengabdian kepada masyarakat dalam bentuk penyuluhan hukum tentang upaya penanggulangan tindak pidana Narkotika di kalangan remaja dapat dilaksakanan secara berkesinambungan dengan peserta Anggota Karang Taruna di Kelurahan yang lain sehingga dapat memberikan pengetahuan dan pemahaman tentang upaya penanggulangan tindak pidana Narkotika di kalangan remaja. Kedua, Kiranya kegiatan pengabdian kepada masyarakat dalam bentuk penyuluhan hukum tentang upaya penanggulangan tindak pidana Narkotika di kalangan remaja dapat dilaksanakan secara terjadwal dengan melibatkan mahasiswa Fakultas Hukum Universitas Bhayangkara sebagai salah satu kegiatan akademik di luar jadwal perkuliahan sehingga dapat memberikan bekal pengalaman kepada mahasiswa di masyarakat.

\section{Ucapan Terima Kasih}

Pelaksanaan kegiatan pengabdian kepada masyarakat dalam bentuk penyuluhan hukum ini dapat terlaksana dengan lancar, oleh karena itu pada kesempatan ini kami menyampaikan ucapan terima kasih yang setinggi-tingginya kepada Lurah Kelurahan Sekola beserta staf yang telah mendukung pelaksanaan kegiatan penyuluhan, dan Ketua dan seluruh anggota Karang Taruna RW 06 Kelurahan Sekeloa yang telah berpartisipasi dan mengikuti kegiatan penyuluhan.

\section{Daftar Pustaka}

Ali, Z. (2008). Sosiologi Hukum. Jakarta: Sinar Grafika.

Arief, B. N. (2010). Bunga Rampai Kebijakan Hukum Pidana. Bandung: Citra Aditya Bakti.

Makaro, M., \& Taufik. (2005). Tindak Pidana Narkotika. Bogor: Ghalia Indonesia.

Rahardjo, S. (2010). Sosiologi Hukum; Perkembangan Metode dan Pilihan Masalah. Yogyakarta: Genta Publishing.

Saebani, B. A. (2006). Sosiologi Hukum. Bandung: Pustaka Setia.

Sasangka, H. (2003). Narkotika dan Psikotropika dalam Hukum Pidana. Bandung: Mandar Maju.

Siswanto, S. (2012). Politik Hukum dalam Undang-Undang Narkotika (UU Nomor 35 Tahun 2009). Jakarta: Rineka Cipta.

Suadi, H. A. (2019). Sosiologi Hukum; Penegakan, Realitas \& Nilai Moralitas Hukum. Jakarta: Kencana. 
Rahman Amin, Iren Manalu, Muh Fikri Al Aziz, Ishanti Nurjanah Rahayu, Winda Apricilya Van Hemert, Alffin Pratama, Indah Tri Lestari

Sujono, A. ., \& Daniel, B. (2013). Komentar dan Pembahasan Undang-Undang Nomor 35 Tahun 2009 tentang Narkotika. Jakarta: Sinar Grafika.

Wresniworo. (1999). Narkotika, Psikotropika dan Obat Berbahaya. Jakarta: Yayasan Mitra Bintibmas Bina Dharma Pemuda. 